\title{
PENGARUH KINERJA LINGKUNGAN, KEPEMILIKAN INSTITUSIONAL, UKURAN PERUSAHAAN DAN LEVERAGE TERHADAP KUALITAS PENGUNGKAPAN LINGKUNGAN
}

\section{Kris Money Terry dan Asrori}

Universitas Negeri Semarang, Surakarta, Jawa Tengah, Indonesia

Email: kristerry98@gmail.com dan asroriunnes@mail.unnes.ac.id

\section{Abstract}

This study aims to obtain evidence regarding the effect of environmental performance, institutional ownership, firm size, and leverage on the quality of environmental disclosure with profitability as a moderating factor. This study uses population of all non-financial companies listed on Indonesia Stock Exchange (IDX) for 2017-2019. This study used purposive sampling to determinate the sample and obtain 60 unit analysis. The method of data analysis in this study is moderated regression analysis (MRA) and using SPSSS 21. The results of this study indicate that environmental performance and institutional ownership have an effect on the quality of environmental disclosure. The results of the moderating effect test show that profitability can moderate the relationship between environmental performance and institutional ownership on the quality of environmental disclosure, while profitability does not moderate the relationship between firm size and leverage on the quality of environmental disclosure. The conclusion of this research is that environmental performance and institutional ownership have a positive effect on the quality of environmental disclosure and profitability can moderate the relationship between environmental performance and institutional ownership on the quality of environmental disclosure.

Keyword: environmental performance; institutional ownership; firm size; leverage; quality of environmental performance.

\section{Abstrak}

Penelitian ini bertujuan untuk mengetahui pengaruh kinerja lingkungan, kepemilikan institusional, ukuran perusahaan, dan leverage terhadap kualitas pengungkapan lingkungan dengan profitabilitas sebagai pemoderasi. Metode analisis data penelitian ini adalah moderated regression analysis (MRA) dengan menggunakan SPSS 21. Populasi dalam penelitian ini adalah seluruh perusahaan non-keuangan yang terdaftar di Bursa Efek Indonesia (BEI) tahun 2017-2019. Penelitian ini menggunakan purposive sampling dan diperoleh sebanyak 60unit analisis. Hasil penelitian ini menunjukan bahwa kinerja lingkungan dan kepemilikan institusional berpengaruh terhadap kualitas pengungkapan lingkungan, sedangkan ukuran perusahaan dan leverage tidak berpengaruh terhadap kualitas pengungkapan lingkungan. Hasil uji pengaruh moderating menunjukan bahwa profitabilitas dapat memoderasi hubungan antara kinerja lingkungan dan kepemilikan institusional terhadap kualitas pengungkapan lingkungan, sedangkan profitabilitas tidak 
memoderasi hubungan antara ukuran perusahaan dan leverage terhadap kualitas pengungkapan lingkungan. Simpulan dari penelitian ini adalah variabel kinerja lingkungan dan kepemilikan institusional berpengaruh positif terhadap kualitas pengungkapan lingkungan dan profitabilitas dapat memoderasi hubungan antara kinerja lingkungan dan kepemilikan institusional terhadap kualitas pengungkapan lingkungan.

Kata kunci: kinerja lingkungan; kepemilikan institusional; ukuran perusahaan; leverage; kualitas pengungkapan lingkungan.

Coresponden Author

Email: kristerry98@gmail.com Artikel dengan akses terbuka dibawah lisensi

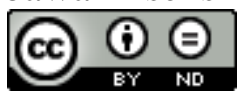

\section{Pendahuluan}

Permasalahan lingkungan di Indonesia sudah semakin mengkhawatirkan mulai dari pencemaran tanah, pencemaran air, pencemaran udara, perubahan iklim, longsor dan bencana lingkungan lainnya. Bentuk konkrit kepedulian pemerintah Indonesia yaitu dengan menjadi salah satu dari 193 kepala negara dan pemerintahan yang ikut menyepakati agenda pembangunan universal baru yang tertuang dalam dokumen berjudul Transforming Our World: The 2030 Agenda for Sustainable Development yang berisi 17 tujuan dan 169 sasaran yang berlaku mulai tahun 2015 hingga tahun 2030. Dokumen ini dikenal dengan istilah Sustainable Development Goals atau SDGs. Salah satu tujuan SDGs menjadi target Indonesia dalam pilar pembangunan lingkungan yang memenuhi tujuan air bersih dan sanitasi yang layak, kota dan pemukiman yang berkelanjutan, konsumsi dan produksi yang bertanggung jawab, penanganan perubahan iklim, ekosistem lautan, dan ekosistem daratan.

Salah satu regulasi tingkat internasional yang mengatur tentang laporan keberlanjutan adalah Global Reporting Initiative (GRI). Global Reporting Initiative terdiri dari 3 tema yaitu ekonomi, sosial, dan lingkungan. Ketiga tema ini dikenal dengan konsep triple bottom line yaitu perusahaan dalam mencapai tujuannya tidak hanya mecapai keuntungan, namun juga bertanggung jawab terhadap masyarakat dan lingkungan (Muallifin dan Priyadi, 2016). GRI Standards diluncurkan setelah GRI-G4 yang sebelumnya sudah menjadi pedoman bagi penulisan laporan keberlanjutan di Indonesia. Perbedaan pada struktur penulisan dalam Golbal Reportimg Initiative Standars ini terdapat klausul yang harus dipenuhi (requirements) dan yang direkomendasikan (recommendations) sehingga memudahkan dalam penyusunan laporan keberlanjutan untuk menentukan prioritas dalam penulisan informasi di laporan keberlanjutan. Regulasi internasional lainnya adalah International Organization for Standardization (ISO) yang menetapkan ISO 14001:2015 tentang sistem manajemen lingkungan. Sistem manajemen lingkungan membantu organisasi mengidentifikasi, mengelola, memantau dan mengendalikan masalah lingkungan secara menyeluruh. ISO 
14001:2015 cocok untuk semua jenis organisasi, baik perusahaan perseorangan, perusahaan non profit ataupun pemerintahan.

Pemerintah Indonesia juga telah mewajibkan perusahaan untuk mengungkapkan tanggung jawab sosial dan lingkungan hidup dalam laporan keberlanjutan (sustainability report) dan laporan tahunan (annual report) perusahaan. Laporan keberlanjutan (sustainability report) bersifat mandatory atau wajib seperti yang ditulis di Undang - Undang Nomor 40 Tahun 2007 tentang Perseroan Terbatas dan Peraturan Otoritas Jasa Keuangan Nomor 51 /POJK.03/2017 tentang Penerapan Keuangan Berkelanjutan Bagi Lembaga Jasa Keuangan, Emiten, dan Perusahaan Publik. Kementrian Lingkungan Hidup dan Kehutanan menyatakan bahwa pengungkapan lingkungan digunakan oleh suatu institusi untuk mengungkapkan data yang berhubungan dengan lingkungan, disahkan atau tidak, mengenai resiko lingkungan, dampak lingkungan, kebijakan, strategi, target biaya, pertanggungjawaban atau environmental performance kepada pihak-pihak yang memiliki kepentingan terhadap informasi dengan tujuan untuk meningkatkan nilai hubungan dengan institusi atau organisasi yang memberi laporan.

Penelitian terdahulu mengenai kualitas pengunkapan lingkungan masih menghasilkan temuan yang inkonsisten sehingga ditemukan adanya research gap. Penelitian yang dilakukan oleh Baalouch et al., (2019), Sri dan Amir (2017), dan Lu dan Taylor (2018) menyebutkan bahwa kinerja lingkungan berpengaruh positif terhadap kualitas pengungkapan lingkungan. Hal tersebut berbeda dengan hasil penelitian yang dilakukan oleh Aboagye-Otchere et al., (2020) yang menyebutkan bahwa kinerja lingkungan berpengaruh negatif terhadap kualitas pengungkapan lingkungan.

Penelitian yang dilakukan oleh Solikhah dan Winarsih (2016), Rupley et al., (2012), dan Ismail et al., (2018) menyatakan bahwa kepemilikan institusional berpengaruh negatif terhadap kualitas pengungkapan lingkungan. hal tersebut bertolak belakang dengan hasil penelitian yang dilakukan oleh Sudarno yang menyatakan bahwa kepemilikan institusional berpengaruh positif terhadap kualitas pengungkapan lingkungan.

Penelitian mengenai pengaruh ukuran perusahaan terhadap kualitas pengungkapan lingkungan juga masih menunjukkan hasil inkonsiten seperti yang ditemukan oleh van de Burgwal dan Vieira (2014) yang menyatakan bahwa ukuran perusahaan berhubungan positif terhadap kualitas penguungkapan lingkungan. Berbanding terbalik dengan penelitian yang dilakukan oleh Oktariyani (2016) dan Dibia dan Onwuchekwa (2015) yang menyatakan bahwa ukuran perusahaan berpengaruh negatif terhadap kualitas dari pengungkapan lingkungan.

Penelitian mengenai pengaruh leverage terhadap kualitas pengungkapan lingkungan yang dilakukan oleh Sulaiman et al., (2014) dan Ohidoa et al., (2016) menghasilkan hasil positif dimana artinya adalah dengan tingkat leverage perusahaan yang tinggi akan menghasilkan kualitas pengungkapan lingkungan yang baik. Hasil yang berbeda ditemukan oleh Febri dan Linda (2015) dimana leverage berpengaruh negatif terhadap kualitas pengungkapan lingkungan. 
Berdasarkan beberapa penelitian diatas menujukkan bahwa masih terdapat hasil yang tidak konsisten sehingga tujuan penelitian ini adalah untuk mengetahui pengaruh kinerja lingkungan, kepemilikan institusional, ukuran perusahaan, dan leverage terhadap kualitas pengungkapan lingkungan. penelitian ini memunculkan variabel profitabilitas sebagai variabel moderating dengan asumsi bahwa perusahaan dengan profitabilitas yang tinggi akan memiliki ketersediaan dana yang lebih sehingga dapat melakukan pengungkapan lingkungan dan menghasilkan kualitas yang lebih baik.

Teori yang digunakan dalam penelitian ini adalah teori legitimasi, teori agensi, dan teori stakeholder. Teori legitimasi adalah kontrak sosial antara perusahaan dengan masyarakat (Ghozali dan Chariri, 2014). Organisasi akan berusaha untuk membangun keselarasan antara nilai-nilai sosial yang ada dalam organisasi dengan norma perilaku yang dapat diterima dalam masyarakat. Pengungkapan lingkungan merupakan salah satu cara perusahaan untuk mendapat legitimasi dari masyarakat karena merupakan bentuk tanggung jawab perusahaan kepada masyarakat. Teori agensi merupakan teori yang muncul karena adanya hubungan antara agent dan principal. Teori agensi menjelaskan bahwa semua individu bertindak atas kepentingan mereka sendiri. Prinsipal dalam hal ini adalah pemegang saham hanya tertarik kepada hasil keuangan yang bertambah atau investasi mereka di dalam perusahaan. Sedangkan para agen akan menerima kepuasan berupa kompensasi keuangan dan syarat-syarat yang menyertai dalam hubungan tersebut (Jensen dan Meckling, 1997). Teori stakeholder adalah teori yang menggambarkan kepada pihak mana saja perusahaan bertanggungjawab (Freeman dan David, 1983). Perusahaan bukanlah entitas yang melakukan kegiatan operasinya untuk memenuhi kepentingan sendiri melainkan juga perusahaan harus memberikan manfaat keberadaaannya bagi stakeholdernya (shareholders, kreditor, supplier, konsumen, masyarakat, pemerintah, dan pihak lain).

Adapun hipotesis yang diajukan dalam penelitian ini yaitu sebagai berikut: Perusahaan dengan kinerja lingkungan yang baik akan melakukan pengungkapan lingkungan yang lebih banyak karena sebagai bentuk akuntabilitas terhadap publik untuk memberikan informasi tentang aspek lingkungan sehingga perusahaan akan memastikan bahwa kegiatan yang dilakukan perusahaan dapat diterima oleh masyarakat: H1: Kinerja lingkungan berpengaruh positif terhadap kualitas pengungkapan lingkungan. Tingkat kepemilikan institusional yang besar dalam suatu perusahaan akan memperbesar kontrol investor terhadap perusahaan, sehingga besarnya kepemilikan institusi dapat menjadi salah satu alasan pengungkapan yang dilakukan perusahaan: H2: Kepemilikan instititusional berpengaruh positif terhadap kualitas pengungkapan lingkungan. Perusahaan besar juga akan mengalami tekanan sosial dan politik yang lebih besar daripada perusahaan kecil karena aktivitas yang dilakukan oleh perusahaan besar akan lebih menarik perhatian masyarakat dan stakeholder sehingga semakin besar ukuran suatu perusahaan maka akan semakin besar probabilitas perusahaan untuk mengungkapkan pengungkapan lingkungan semakin banyak: H3: Ukuran perusahaan berpengaruh positif terhadap kualitas pengungkapan lingkungan. Perusahaan dengan tingkat leverage yang tinggi akan membuktikan kepada publik 
bahwa perusahaan juga mampu memenuhi tanggung jawab terhadap lingkungan dan dampak dari aktivitas yang dihasilkan oleh perusahaan: H4: Leverage berpengaruh positif terhadap kualitas pengungkapan lingkungan.

Profitabilitas dapat digunakan untuk mengukur kesuksesan keuangan secara keseluruhan dan sebagai barometer bagi manajemen dalam menilai seberapa baik strategi yang ditetapkan. Semakin besar laba yang dihasilkan oleh perusahaan maka perusahaan memiliki sumber dana yang besar untuk melakukan pengungkapan lingkungan: H5: Profitabilitas memoderasi pengaruh kinerja lingkungan terhadap kualitas pengungkapan lingkungan. Tingkat profitabilitas yang tinggi juga akan membuat pihak institusional menjadi lebih meningkatkan pengawasan mereka kepada perusahaan agar perusahaan selain memiliki profitabilitas yang tinggi tetapi juga akan menekan perusahaan untuk melakukan aktivitas yang menambah citra positif perusahaan dimata masyarakat menjadi lebih baik: H6: Profitabilitas memoderasi pengaruh kepemilikan institusional terhadap kualitas pengungkapan lingkungan. Profitabilitas yang tinggi juga akan membantu perusahaan dalam melakukan pengungkapan lingkungan yang lebih baik karena perusahaan besar yang memiliki tingkat profitabilitas yang tinggi akan memiliki ketersediaan dana yang lebih untuk dapat melakukan pengungkapan lingkungan lebih banyak sehingga kualitas dari pengungkapan lingkungan akan menjadi lebih baik: H7: Profitabilitas memoderasi pengaruh ukuran perusahaan terhadap kualitas pengungkapan lingkungan. Perusahaan yang memiliki tingkat leverage yang lebih tinggi akan lebih banyak mengungkapkan pengungkapan lingkungan untuk membuktikan kepada masyarakat bahwa perusahaan memiliki tanggung jawab terhadap lingkungan dan dampak yang ditimbulkan oleh aktivitas perusahaan sangat rendah: H8: Profitabilitas memoderasi pengaruh leverage terhadap kualitas pengungkapan lingkungan.

\section{Metode Penelitian}

Penelitian ini menggunakan metode kuantitaif dan data diolah menggunakan teknik moderated regression analysis (MRA). Moderated regression analysis (MRA) menurut Ghozali (2013) adalah pendekatan analitik yang mempertahankan integritas sampel dan memberikan dasar untuk mengontrol pengaruh variabel moderator. Data yang digunakan dalam penelitian ini adalah perusahaan non-keuangan yang terdaftar di Bursa Efek Indonesia (BEI) yang melaporkan anuual report dan sustainability reportsustainability report. Populasi pada penelitian ini adalah perusahaan nonkeuangan yang terdaftar di Bursa Efek Indonesia (BEI) pada tahun 2017 - 2019 dan pengambilan sampel dipilih dengan menggunakan metode purposive sampling dan diperoleh 20 perusahaan dengan periode pengamatan 3 tahun sehingga unit analisis sebanyak 60. Kriteria penentuan sampel dijelaskan pada tabel 1. 
Tabel 1

Kriteria Penentuan Sampel

\begin{tabular}{llc}
\hline No & Kriteria & Jumlah \\
\hline $\mathbf{1}$ & $\begin{array}{l}\text { Perusahaan non-keuangan yang terdaftar di BEI dan } \\
\text { melaporkan laporan tahunan tahun 2017-2019 }\end{array}$ & 86 \\
\hline $\mathbf{2}$ & $\begin{array}{l}\text { Perusahaan non-keuangan yang melaporkan laporan } \\
\text { keberlanjutan tahun 2017-2019 }\end{array}$ & 60 \\
\hline & Jumlah unit analisis 2017 - 2019 (3 tahun) & 60 \\
\hline
\end{tabular}

Sumber: Data sekunder yang diolah, 2020

Variabel dependen dalam penelitian ini adalah kualitas pengungkapan lingkungan sedangka variabel independen dalam penelitian ini adalah kinerja lingkungan, kepemilikan institusional, ukuran perusahaan, dan leverage. Penelitian ini juga menghadirkan profitabilitas sebagai variabel moderating. Definisi operasional dari masing-masing variabel yang digunakan dalam penelitian ini disajikan dalam tabel 2.

Tabel 2

Definisi Operasional Variabel

\begin{tabular}{|c|c|c|}
\hline Variabel & Indikator & Pengukuran \\
\hline $\begin{array}{l}\text { Kualitas } \\
\text { Pengungkapan } \\
\text { Lingkungan }\end{array}$ & $\begin{array}{l}\text { Kualitas informasi dari } \\
\text { pengungkapan lingkungan }\end{array}$ & $\begin{array}{l}\text { Environmental Disclosure Index } \\
\text { Scorecard } \\
\text { (Compliance, Pollution } \\
\text { Prevention, Product } \\
\text { Stewardship, dan Sustainable } \\
\text { Development) yang terdapat } \\
\text { pada annual report dan } \\
\text { sustainability report }\end{array}$ \\
\hline Kinerja Lingkungan & $\begin{array}{l}\text { Upaya perusahaan yang } \\
\text { berkaitan dengan lingkungan } \\
\text { hidup berdasarkan sertifikasi } \\
\text { ISO } 14001\end{array}$ & $\begin{array}{l}\text { Variabel dummy } \\
\text { Perusahaan yang memiliki } \\
\text { sertifikasi ISO } 14001 \text { memiliki } \\
\text { nilai } 1 \\
\text { Perusahaan yang tidak memiliki } \\
\text { sertifikasi ISO } 14001 \text { memiliki } \\
\text { nilai } 0\end{array}$ \\
\hline \multirow{2}{*}{$\begin{array}{l}\text { Kepemilikan } \\
\text { Institusional }\end{array}$} & \multirow[b]{2}{*}{$\begin{array}{l}\text { Kepemilikan jumlah saham } \\
\text { perusahaan oleh } \\
\text { lembaga/institusi seperti } \\
\text { perusahaan reksa dana, dana } \\
\text { pension, asuransi, maupun } \\
\text { perusahaan investasi lainnya }\end{array}$} & Kepemilikan Saham Institusi \\
\hline & & Total Saham Beredar \\
\hline Ukuran Perusahaan & $\begin{array}{l}\text { Ukuran perusahaan } \\
\text { berdasarkan total penjualan } \\
\text { yang dimiliki perusahaan }\end{array}$ & $\begin{array}{l}\text { Log Natural dari Total } \\
\text { Penjualan (Ln Sales) }\end{array}$ \\
\hline Leverage & $\begin{array}{l}\text { Kemampuan perusahaan } \\
\text { untuk membayar hutangnya } \\
\text { dengan menggunakan ekuitas }\end{array}$ & DER $=\frac{\text { Total Hutang }}{\text { Ekwitas }}$ \\
\hline
\end{tabular}


yang dimiliknya

Profitabilitas $\quad \begin{aligned} & \text { Kemampuan perusahaan } \\ & \text { dalam menghasilkan laba }\end{aligned} \quad \mathrm{ROA}=\frac{\text { lababersih setelah pajak }}{\text { total aset }}$

Sumber: Berbagai referensi, 2020

Teknik pengumpulan data dalam penelitian ini yaitu dengan teknik dokumentasi dengan mengunduh laporan tahunan dan laporan keberlanjutan di Bursa Efek Indonesia (BEI) yaitu www.idx.com dan dari website perusahaan. Metode analisis yang digunakan dalam penelitian ini adalah moderated regression analysis (MRA) dengan menggunakan SPSS 21.

\section{Hasil dan Pembahasan}

Statistik deskriptif digunakan untuk melihat rata-rata (mean), maksimum, minimum, dan standar deviasi variabel kualitas pengungkapan lingkungan, kinerja lingkungan, kepemilikan institusional, ukuran perusahaan, leverage, dan profitabilitas. Hasil dari statistik deskriptif adalah sebagai berikut:

\section{Tabel 3}

Statistik Deskriptif

\begin{tabular}{lcrrrr}
\hline & $\mathrm{N}$ & $\begin{array}{c}\text { Minimu } \\
\mathrm{m}\end{array}$ & $\begin{array}{c}\text { Maximu } \\
\mathrm{m}\end{array}$ & Mean & \multicolumn{1}{c}{$\begin{array}{c}\text { Std. } \\
\text { Deviation }\end{array}$} \\
\hline $\begin{array}{l}\text { Kepemilikan } \\
\text { Institusional }\end{array}$ & 60 & .4900 & .9871 & .688233 & .1251119 \\
\hline Ukuran Perusahaan & 60 & 27.14 & 33.10 & 30.2976 & 1.27367 \\
\hline Leverage & 60 & .0227 & 2.8700 & 1.09264 & .7401260 \\
& & & & 8 & \\
\hline ROA & 60 & -.0600 & 13.8000 & .431443 & 2.0356771 \\
\hline $\begin{array}{l}\text { Kualitas } \\
\text { Pengungkapan }\end{array}$ & 60 & 13 & 75 & 45.35 & 14.704 \\
\hline Valid N (listwise) & 60 & & & & \\
\hline
\end{tabular}

Sumber: Data sekunder yang diolah, 2020.

Hasil uji statistik deskriptif menunjukkan bahwa variabel kualitas pengungkapan lingkungan memiliki nilai tertinggi sebesar 75 yang dimiliki oleh PT Timah Tbk tahun 2019. Sedangkan nilai terendah sebesar 13 dimiliki oleh PT Adhi Karya Tbk tahun 2017 dan PT Indika Energy Tbk tahun 2018. Nilai rata-rata lebih besar dari standar deviasi sehingga menunjukkan bahwa sebaran data kualitas pengungkapan lingkungan menyebar secara heterogen.

Analisis dalam statistik deskriptif lain yang digunakan peneliti adalah dsitribusi frekuensi yang digunakan untuk variabel kinerja lingkungan yang merupakan variabel dummy dalam penelitian ini. Distribusi frekuensi menurut Riduwan (2003) adalah 
penyusunan suatu data dari yang terkecil sampai terbesar yang membagi banyaknya data dalam beberapa kelas.

Tabel 4

Hasil Distribusi Frekuensi

\begin{tabular}{crrrrr}
\hline & & Frequency & Percent & Valid Percent & \multicolumn{2}{c}{$\begin{array}{c}\text { Cumulative } \\
\text { Percent }\end{array}$} \\
\hline Valid & 0 & 12 & 20.0 & 20.0 & 20.0 \\
\cline { 2 - 6 } & 1 & 48 & 80.0 & 80.0 & 100.0 \\
\cline { 2 - 6 } & & & & & \\
\hline
\end{tabular}

Berdasarkan hasil distribusi frekuensi pada tabel 4 dapat diketahui bahwa jumlah perusahaan yang tidak memiliki sertifikasi ISO 14001 adalah 12 perusahaan atau 20\%, sedangkan jumlah perusahaan yang memiliki sertifikasi ISO 14001 adalah 48 perusahaan atau $80 \%$ dari jumlah seluruh perusahaan dalam penelitian ini.

Uji asumsi klasik dalam penelitian ini terdiri dari uji normalitas, uji multikolinieritas, uji autokorelasi, dan uji heteroskedastisitas. Uji normalitas menggunakan uji One Sample Kolmogorov-Smirnov memiliki nilai signifikansi sebesar 0,644 yang lebih besar dari 0,05 sehingga dapat disimpulkan bahwa data berdistribusi normal. Hasil uji multikolinieritas menunjukkan bahwa seluruh variabel memiliki nilai tolerance lebih besar dari 0,10 dan nilai VIF lebih kecil dari 10, sehingga dapat disimpulkan bahwa model regresi ini bebas dari asumsi multikolinieritas. Hasil uji autokorelasi menunjukkan nilai durbin watson sebesar 1,866 yang lebih besar dari nilai dU dan lebih kecil dari 4-dU $(1,761<1,866<2,2329)$, sehingga dapat disimpulkan tidak terjadi autokorelasi dalam penelitian ini. Uji heteroskedadisitas menggunakan uji white dan menunjukkan nilai Rsquare 0,083 dan nilai $c^{2}$ sebesar $60 \times 0,083=4,98$. Nilai $\mathrm{c}^{2}$ tabel diperoleh dari tabel Chi-square dengan tingkat signifikansi 0,05 dengan derajat kebebsan sebesar 5-1=4, sehingga nilai $c^{2}$ tabel adalah sebesar 9,488. Nilai $c^{2}$ hitung lebih kecil daripada nilai $\mathrm{c}^{2}$ tabel sehingga dapat disimpulkan bahwa tidak terjadi heteroskedastisitas dalam model regresi ini.

\section{A. Pengujian Hipotesis}

Hasil uji koefisien determinasi menghasilkan nilai Adjusted $\mathrm{R}$ Square sebesar 0,115. Hal tersebut menunjukan bahwa kemampuan 11,5\% variabel kinerja lingkungan, kepemilikan institusional, ukuran perusahaan, leverage, dan profitabilitas kurang mampu untuk menjelaskan variabel kualitas pengungkapan lingkungan. Sementara sisanya 88,5\% dijelaskan oleh variabel lain diluar model penelitian. Hasil uji moderated regression analysis (MRA) dapat dilihat pada tabel 5 .

\section{Tabel 5}

Ringkasan Hasil Uji Hipotesis

$\begin{array}{lllll}\text { Model } & \begin{array}{c}\text { Unstandardized } \\ \text { Coefficients }\end{array} & \begin{array}{c}\text { Standardized } \\ \text { Coefficients }\end{array} & \text { t } & \text { Sig. }\end{array}$




\begin{tabular}{|c|c|c|c|c|c|}
\hline & B & $\begin{array}{l}\text { Std. } \\
\text { Error }\end{array}$ & Beta & & \\
\hline (Constant) & 52,226 & 3,003 & & 17,389 & 0,000 \\
\hline $\begin{array}{l}\text { Zscore: Kinerja } \\
\text { Lingkungan }\end{array}$ & 8,558 & 2,955 & 0,582 & 2,896 & 0,006 \\
\hline $\begin{array}{l}\text { Zscore: } \\
\text { Kepemilikan } \\
\text { Institusional }\end{array}$ & 6,320 & 2,296 & 0,430 & 2,752 & 0,008 \\
\hline $\begin{array}{l}\text { Zscore: Ukuran } \\
\text { Perusahaan }\end{array}$ & 4,333 & 2,212 & 0,295 & 1,959 & 0,056 \\
\hline Zscore: Leverage & 2,717 & 2,014 & 0,185 & 1,349 & 0,183 \\
\hline kinerja_ROA & 8,539 & 3,943 & 0,720 & 2,166 & 0,035 \\
\hline Kepemilikan_ROA & $-6,788$ & 3,167 & $-0,486$ & $-2,143$ & 0,037 \\
\hline Ukuran_ROA & $-1,379$ & 3,164 & $-0,086$ & $-0,436$ & 0,665 \\
\hline Leverage_ROA & $-9,659$ & 3,476 & $-0,504$ & $-2,778$ & 0,008 \\
\hline
\end{tabular}

Sumber: Data sekunder diolah, 2020

\section{Pengaruh Kinerja Lingkungan Terhadap Kualitas Pengungkapan Lingkungan}

Pengujian hipotesis menunjukkan bahwa kinerja lingkungan berpengaruh positif terhadap kualitas pengungkapan lingkungan (H1 diterima). Hasil penelitian sesuai dengan teori legitimasi yang menjelaskan bahwa perusahaan akan berusaha untuk membangun keselarasan antara nilai sosial dengan kegiatan perusahaan dan norma perilaku yang dapat diterima agar memperoleh legitimasi dari masyarakat. Perusahaan yang memiliki kinerja lingkungan yang baik akan mengungkapkan pengungkapan lingkungan yang lebih banyak karena sebagai bentuk pemenuhan tanggung jawab kepada masyarakat dalam memberikan informasi terkait dengan aktivitas yang dilakukan perusahaan yang bersinggungan dengan lingkungan. Hasil penelitian ini sejalan dengan penelitian yang dilakukan oleh Baalouch et al., (2019) dan Sri dan Amir, (2017) dimana kinerja lingkungan berpengaruh positif signifikan terhadap kualitas pengungkapan lingkungan.

\section{Pengaruh Kepemilikan Institusional Terhadap Kualitas Pengungkapan Lingkungan}

Pengujian hipotesis menunjukkan bahwa kepemilikan institusional berpengaruh positif terhadap kualitas pengungkapan lingkungan ( $\mathrm{H} 2$ diterima). Hasil penelitian ini sejalan dengan teori agensi dimana pemilik institusi sebagai pihak yang mengawasi perilaku manajemen dalam menetapkan segala keputusan perusahaan. Pihak institusional akan menuntut manajemen untuk melakukan pengungkapan lingkungan untuk menjadi bukti pertanggung jawaban perusahaan kepada stakeholder sehingga perusahaan mendapat nilai yang positif bagi dimata stakeholder. Semakin tinggi kepemilikan institusional dalam suatu 
perusahaan akan memperbesar kontrol investor terhadap perusahaan sehingga dapat menjadi salah satu alasan pengungkapan yang dilakukan perusahaan semakin karena sebagai salah satu bentuk tanggung jawab perusahaan terhadap institusi. Penelitian ini sejalan dengan hasil penelitian Nurrahman dan Sudarno (2013) yang menyatakan bahwa kepemilikan institusional berpengaruh terhadap sustainability report.

\section{Pengaruh Ukuran Perusahaan terhadap Kualitas Pengungkapan} Lingkungan

Pengujian hipotesis menunjukkan bahwa ukuran perusahaan tidak berpengaruh terhadap kualitas pengungkapan lingkungan (H3 ditolak). Hasil penelitian ini tidak mendukung teori legitimasi dan stakeholder. Teori legitimasi menjelaskan bahwa perusahaan berusaha meningkatkan kelangsungan hidup perusahaanya dengan memberikan manfaat kepada masyarakat dan para stakeholder sehingga mendapat legitimasi. Ukuran perusahaan tidak mempengaruhi kualitas dari pengungkapan lingkungan karena umumnya perusahaan besar dan perusahaan kecil memiliki masalah keuangannya sendiri sehingga perusahaan besar belum tentu akan mengungkapkan tanggung jawab lingkungan lebih banyak. Besarmya ukuran perusahaan tidak selalu membuat perusahaan mengungkapkan informasi yang lebih banyak dalam pengungkapan lingkungan. Temuan dalam penelitian ini sesuai dengan penelitian Oktariyani (2016) yang menjelaskan bahwa kualitas pengungkapan lingkungan tidak dipengaruhi oleh ukuran perusahaan.

\section{Pengaruh Leverage terhadap Kualitas Pengungkapan Lingkungan}

Pengujian hipotesis menunjukkan bahwa leverage tidak berpengaruh terhadap kualitas pengungkapan lingkungan (H3 ditolak). Hasil penelitian ini tidak sesuai dengan teori stakeholder dan legitimasi yang mendasari pengaruh leverage terhadap kualitas pengungkapan lingkungan. Perusahaan perlu menunjukkan akuntabilitas dan responsibilitasnya kepada stakeholder dan masyarakat. Salah satu bentuk akuntabilitas dari perusahaan yaitu dengan melakukan pengungkapan lingkungan, akan tetapi berdasarkan hasil penelitian ini ditemukan bahwa tidak adanya hubungan antara leverage dengan kualitas pengungkapan lingkungan. Hal ini diduga karena biaya yang dikeluarkan cukup besar untuk melakukan pengungkapan lingkungan. Perusahaan yang memiliki rasio leverage yang tinggi mengindikasikan bahwa perusahaan lebih banyak dibiayai oleh hutang yang nantinya akan mengurangi berbagai pengeluaran yang salah satunya untuk melakukan pengungkapan lingkungan. Hasil penelitian ini sejalan dengan penelitian yang dilakukan oleh Baalouch et al., (2019) dan Afsari et al., (2017) yang menyatakan bahwa leverage tidak berpengaruh terhadap kualitas pengungkapan lingkungan. 


\section{Profitabilitas Memoderasi Pengaruh Kinerja Lingkungan Terhadap Kualitas Pengungkapan Lingkungan}

Hasil penelitian ini menunjukkan bahwa profitabilitas memoderasi pengaruh kinerja lingkungan terhadap kualitas pengungkapan lingkungan. Perusahaan dengan profitabilitas yang tinggi dianggap lebih mampu dalam melaksanakan tuntutan masyarakat karena perusaahaan memiliki ketersediaan dana yang lebih banyak sehingga dapat melakukan pengungkapan lingkungan Hal ini mendukung teori stakeholder yang mengemukakan bahwa perusahaan dengan tingkat profitabilitas yang tinggi cenderung untuk memberikan informasi lingkungan serta biaya lingkungan yang dihasilkan untuk melaporkan pengungkapan sosial dan lingkungan. Kenaikan tingkat profitabiltas semakin memperkuat hubungan antara kinerja lingkungan terhadap kualitas pengungkapan lingkungan yang dibuktikan dengan semakin meningkatnya nilai kualitas pengungkapan lingkungan

\section{Profitabilitas Memoderasi Pengaruh Kepemilikan Institusional Terhadap Kualitas Pengungkapan Lingkungan}

Hasil penelitian ini menunjukkan bahwa profitabilitas memoderasi pengaruh kinerja lingkungan terhadap kualitas pengungkapan lingkungan. Tingkat kepemilikan institusional yang tinggi akan menimbulkan pengawasan yang lebih besar dari pihak investor institusional terhadap perusahaan. Semakin tinggi kepemilikan institusional maka akan semakin tinggi tuntutan mereka untuk melakukan pengungkapan informasi termasuk pengungkapan lingkungan sehingga perusahaan akan memiliki kualitas informasi pengungkapan lingkungan yang lebih baik. Perusahaan dengan tingkat profitabilitas yang tinggi akan memiliki kepatuhan yang tinggi terhadap aturan mengenai lingkungan sehingga perusahaan akan memiliki tanggung jawab lebih untuk melakukan pengungkapan lingkungan. Semaki tingginya profitabilitas, maka pihak institusional akan semakin meningkatkan pengawasan terhadap perusahaan dan akan lebih menuntut perusahaan untuk melakukan pengungkapan lingkungan yang lebih banyak.

7. Profitabilitas Memoderasi Pengaruh Ukuran Perusahaan Terhadap Kualitas Pengungkapan Lingkungan

Hasil penelitian ini menunjukan bahwa profitabilitas tidak memoderasi pengaruh ukuran perusahaan terhadap kualitas pengungkapan lingkungan. Besar kecilnya perusahaan tidak menentukan kualitas dari pengungkapan lingkungan yang dilakukan perusahaan dan terbukti pada hipotesis ketiga penelitian ini yang membuktikan bahwa ukuran perusahaan tidak berpengaruh terhadap kualitas dari pengungkapan lingkungan. Profitabilitas tidak dapat memperkuat ukuran perusahaan untuk mempengaruhi kualitas pengungkapan lingkungan. Hal ini menunjukan bahwa perusahaan besar yang memiliki profitabilitas tinggi belum tentu akan memiliki kualitas pengungkapan lingkungan yang baik. Hal ini membuktikan bahwa profitabilitas dan ukuran perusahaan tidak mempengaruhi tingkat kualitas pengungkapan lingkungan yang dilakukan perusahaan karena 
dapat dilihat bahwa perusahaan dengan profitabilitas dan ukuran perusahaan yang rendah mampu memiliki kualitas pengungkapan lingkungan yang lebih tinggi daripada perusahaan yang memiliki profitabilitas dan ukuran perusahaan yang tinggi.

\section{Profitabilitas Memoderasi Pengaruh Leverage Terhadap Kualitas Pengungkapan Lingkungan}

Hasil penelitian ini menunjukan bahwa profitabilitas tidak memoderasi pengaruh leverage terhadap kualitas pengungkapan lingkungan. Tingkat leverage yang tinggi mengindikasikan beban bunga hutang perusahaan semakin tinggi sehingga perusahaan dengan tingkat rasio leverage yang tinggi akan lebih beresiko dan memiliki ketergantungan terhadap kreditor, dengan tingkat profitabilitas yang tinggi akan lebih memilih untuk mengurangi hutangnya daripada melakukan pengungkapan sosial dan lingkungan yang memakan biaya yang cukup besar. Hal ini menunjukan bahwa perusahaan dengan tingkat leverage dan profitabilitas yang tinggi tidak membuat perusahaan mengungkapkan pengungkapan lingkungan secara keseluruhan sehingga memiliki kualitas yang rendah.

\section{Kesimpulan}

Simpulan dari penelitian ini kinerja lingkungan dan kepemilikan berpengaruh terhadap kualitas pengungkapan lingkungan sedangkan ukuran perusahaan dan leverage tidak berpengaruh terhadap kualitas pengungkapan lingkungan. Profitabilitas hanya dapat memoderasi kinerja lingkungan dan kepemilikan institusional dan tidak dapat memoderasi pengaruh ukuran perusahaan dan leverage terhadap kualitas pengungkapan lingkungan.

Profitabilitas sebagai variabel moderating tidak dapat memoderasi hubungan ukuran perusahaan dan leverage terhadap kualitas pengungkapan lingkungan terhadap kualitas pengungkapan lingkungan. Penelitian selanjutya diharapkan untuk menggunakan variabel moderating lain. Bagi pemerintah diharapkan untuk dapat membuat kebijakan mengenai pengungkapan lingkungan sehingga perusahaan akan lebih memiliki rasa tanggung jawab terhadap lingkungan karena tingkat kesadaran perusahaan terhadap pengungkapan lingkungan masih rendah. Penelitian selanjutnya disarankan untuk menggunakan pengukuran kualitas pengungkapan lingkungan yang tidak terdapat unsur subjektivitas. 


\section{BIBLIOGRAFI}

Aboagye-Otchere, Francis K., Simpson, Samuel Nana Yaw, \& Kusi, John Amoah. (2020). The influence of environmental performance on environmental disclosures: An empirical study in Ghana. Business Strategy and Development, 3(1), 98-111. https://doi.org/10.1002/bsd2.81

Afsari, Rimah, Purnamawati, I. Gusti Ayu, \& Prayudi, Made Aristia. (2017). Pengaruh Leverage, Ukuran Perusahaan, Komite Audit dan Kepemilikan Institusional Terhadap Luas Pengungkapan Sustainability Report (Studi Empiris Perusahaan yang Mengikuti ISRA Periode 2013-2015). E-Jurnal S1 Ak Universitas Pendidikan Ganesha, 8(2), 1-12.

Baalouch, Fatma, Ayadi, Salma Damak, \& Hussainey, Khaled. (2019). A study of the determinants of environmental disclosure quality: evidence from French listed companies. In Journal of Management and Governance (Vol. 23).

Dibia, Ndukwe O., \& Onwuchekwa, John Chika. (2015). Determinants of Environmental Disclosures in Nigeria: A Case Study of Oil and Gas Companies. International Journal of Finance and Accounting.

Febri, Aulia, \& Linda, Agustina. (2015). Pengaruh Karakteristik Perusahaan, Kinerja Lingkungan, Dan Liputan Media Terhadap Environmental Disclosure. Accounting Analysis Journal. https://doi.org/10.15294/aaj.v4i3.8306

Freeman, R. Edward, \& David, L. Reed. (1983). Stockholders and Stakeholders: A New Perspective on Corporate Governance. California Management Review. https://doi.org/10.2307/41165018

Ghozali, Imam., \& Chariri. (2014). Teori Akuntansi. Semarang: Badan Penerbit Universitas Diponegoro.

Ghozali, Imam. (2013). Ghozali, Imam (2013). Aplikasi Analisis Multivariate Dengan Program IBM SPSS 21Update PLS Regresi. Semarang: Badan Penerbit Universitas Diponegoro.

Ismail, Abdullah Hamoud, Abdul Rahman, Azhar, \& Hezabr, Abdulqawi Ahmed. (2018). Determinants of corporate environmental disclosure quality of oil and gas industry in developing countries. In International Journal of Ethics and Systems (Vol. 34). https://doi.org/10.1108/IJOES-03-2018-0042

Lu, Lucy Wenxiang, \& Taylor, Martin Edward. (2018). A study of the relationships among environmental performance, environmental disclosure, and financial performance. Asian Review of Accounting. https://doi.org/10.1108/ARA-01-20160010

Muallifin, Ovi Rizki, \& Priyadi, Maswar Patuh. (2016). Dampak Pengungkapan Sustainability Report Terhadap Kinerja Keuangan dan Kinerja Pasar. Jurnal Ilmu 


\section{Dan Riser Akuntansi.}

Nurrahman, Adimulya, \& Sudarno. (2013). Pengaruh Kepemilikan Manajerial, Kepemilikan Institusional, Dan Kepemilikan Asing Terhadap Praktik Pengungkapan Sustainability Report. Pengaruh Kepemilikan Manajerial, Kepemilikan Institusional, Dan Kepemilikan Asing Terhadap Praktik Pengungkapan Sustainability Report, 2(1), 273-285.

Ohidoa, Toluwa, Omokhudu, Okun .. O., \& Oserogho, Ikhenade A. F. (2016). Determinants of Environmental Disclosure. International Journal of Advanced Academic Research.

Oktariyani, Amanda. (2016). Pengaruh Kinerja Keuangan , Leverage , Ukuran Perusahaan Kuaitas Pengungkapan Lingkungan (Studi Empiris Pada Industri Pertambangan yang Terdaftar di BEI). Jurnal PEenelitian Dan Pengembangan Akuntansi, 10(2), 103-136.

Otoritas Jasa Keuangan. (n.d.). No Peraturan Otoritas Jasa Keuangan Nomor 51 /Pojk.03/2017 Tentang Penerapan Keuangan Berkelanjutan Bagi Lembaga Jasa Keuangan, Emiten, Dan Perusahaan Publik.

Republik Indonesia. (n.d.). Undang - Undang Nomor 40 Tahun 2007 tentang Perseroan Terbatas.

Rupley, Kathleen Hertz, Brown, Darrell, \& Marshall, R. Scott. (2012). Governance, media and the quality of environmental disclosure. Journal of Accounting and Public Policy, 31(6), 610-640. https://doi.org/10.1016/j.jaccpubpol.2012.09.002

Solikhah, B., \& Winarsih, A. M. (2016). Pengaruh Liputan Media, Kepekaan Industri, Dan Struktur Tata Kelola Perusahaan Terhadap Kualitas Pengungkapan Lingkungan (The Effect Of Media Coverage, Industry Sensitivity And Corporate Governance Structure On Environmental Disclosure Quality). Jurnal Akuntansi Dan Keuangan Indonesia, 13(1), 1-22.

Sri, Wahyuni, \& Amir, Mahmud. (2017). Determinant of Environmental Disclosure on Companies Listed in Indonesia Stock Exchange (IDX). Accounting Analysis Journal, 6(3), 380-393. https://doi.org/10.15294/aaj.v6i3.18898

Sulaiman, Maliah, Abdullah, Norhayati, Fatima, A. H., Sciences, Management, Gombak, Jalan, Lumpur, Kuala, Campus, Gong Badak, \& Terengganu, Kuala. (2014). Determinants of Environmental Reporting Quality in Malaysia. IIUM Journal of Economics and Management, 22(1), 63-90.

Van de Burgwal, Dion, \& Vieira, Rui José Oliveira. (2014). Environmental disclosure determinants in Dutch listed companies. Revista Contabilidade \& Finanças - USP.

Whipple, Holly. (2018). Value Engineering and the Lean Start-Up. 2016 Value Summit: The Power of VE 